\title{
CONVENTION, SOCIAL TRUST, AND LEGAL INTERPRETATION
}

\author{
(forthcoming in Social Trust, Kevin Vallier \& Michael Weber, eds., (Routledge, 2021).
}

\author{
Ira K. Lindsay* \\ University of Surrey School of Law
}

\begin{abstract}
This chapter argues that the importance of trust between actors within the legal system has important implications for legal method. Governance by law is a conventional practice. Conscientious officials prefer to follow the law if other officials do so as well, even at some cost to their other aims. But they are unlikely to do so when the law conflicts with their other goals unless they believe that officials with differing moral or political views will also follow the law in similar circumstances. For this reason, trust between actors in the legal system plays an important role in creating and maintaining the rule of law. This has implications for both legal interpretation and institutional design. In general, we should prefer legal methodologies that increase agreement about the content and proper application of the law independently of any epistemic considerations. Theories of statutory interpretation should therefore be chosen in part on the basis of how much agreement they generate between different interpreters. Different methodologies may be preferable in different areas of law. Textualist methodology may yield greater agreement in areas of law in which pervasive moral disagreement generates stark differences in legal intuitions, while purposivist methodologies may be preferable in areas of law in which there is wide convergence in judgment about the underlying normative issues. The result is a modest relativism about interpretive method.
\end{abstract}

\footnotetext{
* The author would like to thank the editors for helpful comments as well as participants in the Bowling Green State University Conference on Social Trust, in staff research seminars at the University of Surrey School of Law and at the University of Bergen Faculty of Law, and in the 2020 Tax Research Network Conference. The author also wishes to thank Benita R. Mathew for research assistance.
} 
Governance by law is a conventional practice. By this I mean that following the law, as opposed to acting on one's best non-legal reasons, is a convention. Government officials, including judges, civil servants, government lawyers, and legislators are charged with interpreting and applying the law in a great range of situations in which they have some discretion as to how to act. Rule by law (rather than by personal command, decree or whim), requires that they attach a great deal of importance to what the law tells them. Conscientious officials should prefer to follow the law, even at some cost to their other aims. But they are unlikely to do so unless they believe that other actors who might have differing moral or political views will also follow the law. In part this is because if one's political rivals do not follow the law, it is hard not to feel unfairly disadvantaged if one follows the law at some cost to one's own normative principles or material interests. In part this is because law cannot perform its coordinating function if legal officials ignore the law when they find it convenient to do so. There is little point to being a lone law-abiding official.

If this analysis is correct, we should expect social trust to play a large causal role in creating and maintaining rule by law. In a high trust environment, officials might go to great lengths to faithfully interpret and apply the law even when doing so does not result in their preferred outcome. In a low trust environment, officials might pay lip service to the law but largely ignore it to the extent that they can do so without being sanctioned. Frequent, serious violations of law by officials undermine trust and encourage others to ignore the law. Since any political system has a limited ability to monitor and sanction its officials, legal systems with low trust between officials will tend to degenerate. Similarly, disagreements between legal officials about the content or proper application of the law will tend to undermine the trust between officials that enables the system to function effectively. 
The importance of trust between legal actors provides strong reasons to prefer legal methods that increase agreement about the content and proper application of the law independently of any epistemic considerations. This insight has significant import for both legal interpretation and institutional design. Methodologies for legal interpretation should be chosen in part on the basis of how much agreement about the content and application of the law they generate between different interpreters. There is long-running debate between textualists and purposivists over methodology in statutory interpretation. Textualists tend to favour interpretive methodologies that require that interpreters consider only the statutory text whereas purposivists favour broader inquiry in the aims of the statute that may involve consideration of other materials such as legislative history. People interpreting legal texts rely on intuitive judgments (moral, legal or otherwise). A crucial question for any given domain of law is the extent to which actors within a legal system converge in their intuitive judgments. My argument yields an argument in favour of textualist methodology in areas of law (e.g. constitutional law) in which pervasive moral disagreement generates stark differences in legal intuitions. But it counsels adoption of purposivist methodologies in areas of law in which there is wide convergence in judgment about the underlying normative issues (e.g. provisions of the tax code should be understood, whenever possible, in such a way that tax treatment reflects economic substance). In other words, formalistic interpretative methods are useful for increasing trust when legal actors do not agree on background principles, but may actually decrease legal certainty in areas in which there is broad agreement on the moral considerations at stake. The result is a modest relativism about interpretive method.

The argument will unfold in three stages. The first part will argue that rule by law is a convention because willingness to follow the law for its own sake depends on expectations about the behaviour of other legal officials. The second part explores the role of trust between legal officials in maintaining the legal system. The third part traces implications of the role of 
trust in the legal system for legal interpretation. The three arguments build upon each other. It is possible to accept the first stages of the analysis while rejecting my normative conclusions. Likewise, the normative conclusions might be appealing for reasons other than those offered here.

\section{Trust and the Rule of Law: Preliminary Matters}

One might distinguish between two different ways in which social trust is important to the legal system. What I will call vertical trust refers to the relationship between legal officials and legal subjects. It concerns whether legal subjects trust legal officials to apply the laws fairly and impartially and whether legal officials trust that legal subjects will obey legally valid directives. Vertical trust is crucially important for perceptions of the legitimacy of the legal system and of the government and therefore in determining whether legal subjects follow the law. (Tyler 1990, 161-165). Horizontal trust is concerned with the attitude legal officials take toward one another. ${ }^{1}$ Highly trusting legal officials tend to believe that other officials can be trusted to apply the law fairly and impartially without extensive monitoring or heavy-handed sanctions. This does not mean that all legal officials agree on the content of the law in every instance, but instead that they expect other officials to make a good faith effort to get it right. A low trust system in this sense is one in which officials do not expect other officials to apply the law impartially but rather to make decisions on non-legal grounds, at least when they can avoid sanctions for doing so. The argument in this paper is concerned with horizontal trust in the legal system rather than vertical trust. ${ }^{2}$

\footnotetext{
1 'Horizontal trust' sometimes refers to the bonds of trust between citizens (Lenard 2015, 353). The terminology seems applicable here as well since the reciprocal relationships among citizens and among legal officials contrasts with the hierarchical relationship between legal officials and citizens.

${ }^{2}$ A final sense of trust is the trust the legal system places in legal officials when giving them discretion to interpret, construct or create the law (Shapiro 2011, 331-52). This is not what I mean by trust here. Rather than the attitude of the legal system toward officials, I am concerned with the attitude of legal officials toward one another.
} 
It should be immediately conceded that a high trust legal system is not necessarily a good thing. High horizontal trust between legal officials enables the officials to better pursue their ends whether they are for good or for ill. Trust makes it easier for officials to implement oppressive legal regimes as well as benevolent ones. This might go some way toward explaining the historically common pattern for governments to be dominated by a minority, defined in some way — whether by ethnicity, language or religion — that sets them apart from the governed masses. This presumably increases trust between government officials while lowering the odds that some branch of government will be captured by some part of the governed population. Most obviously, familial ties between the governing and the governed raise the risk that government officials will act in the interests of their family members rather than in those of the state. ${ }^{3}$ To the extent that a government builds horizontal trust between legal officials by employing officials that are unrepresentative of the larger population, this will tend to reduce vertical trust. ${ }^{4}$

Horizontal trust is principally a concern for well-developed legal systems administered by legal specialists. Some degree of trust between legal subjects is necessary for such a system to emerge in the first place. There is an interesting literature, on the conventional roots of legal order that can be traced to David Hume (1886). This tradition suggests that much of the core of private law, especially property and contract, may evolve from repeated interactions between mostly self-interested agents who face a coordination problem. More recently, Gillian Hadfield and Barry Weingast (2012) have argued that the characteristics associated with the rule of law

\footnotetext{
${ }^{3}$ The Ottoman Empire and Mamluk Egypt addressed this problem by conscripting or buying children from outside the governing class to form the next generation of government officials so that officials would have no family ties outside the state and could not aspire to pass on their political power to their own children (Turchin and Nefedov 2009, 24-25).

${ }^{4}$ As Andreas Bergh, Christian Bjørnskov, \& Kevin Vallier (2021) point out elsewhere in this volume, although trust in the legal system is typically associated with social trust in the society as a whole, this linkage may be broken if agents of the legal system are seen as unrepresentative of the larger society.
} 
— generality, stability, openness and impersonality - emerge from the conventions necessary to support a system of private decentralized enforcement of norms regulating collective punishment. My focus is somewhat different from theirs. I will analyse conventions concerning the application of the law by agents of the state rather than those concerning obedience to the law by legal subjects or creation of the law by either group.

The notion of trust employed in my argument is, in most respects, a thin one. It is at least primarily cognitive as opposed to non-cognitive or affective. ${ }^{5}$ This means that trust is connected to the beliefs of the trusting party about the future behaviour of the trusted party (Hardin 2006, 19; Sztompka 2000, 25-27). Trust is responsive to evidence about the trustworthiness of others. Trust in officials to follow the law might have an affective component in some instances, but it might be also displayed by people who take a rather coldbloodedly calculating attitude toward the prediction of officials' future actions. Trust is part of a three-place relation between a party who trusts, a trusted party and a domain in which the trusted party is trusted (Domenicucci and Holton 2017, 149-160). The argument in this chapter will be concerned with trust in legal officials to follow the law. It is consistent with various cognitive theories of trust. For example, Russell Hardin's $(2006,19)$ encapsulated interest account of trust holds that a trusting party trusts a trusted party in some domain when the trusting party believes that the trusted party will act in the interest of the trusting party because the trusting party's interests are encapsulated in the interests of the trusted party. In this case, the way in which interests are encapsulated is via a shared normative commitment to following the law. Because this sort of trust involves reliance on normative commitment, the argument in this chapter is consistent with certain theories of trust that are more demanding than Hardin's. For example, Philip Nickel $(2009,353)$ defends a view of trust as risky reliance on what one

\footnotetext{
${ }^{5}$ For the distinction between cognitive and non-cognitive theories of trust, see Becker (1996) and Jones (1996).
} 
morally expects another to do. On other words, trust involves a prediction that another will act according to a certain moral standard. Trust in officials to comply with their moral obligations to apply the law faithfully would fit Nickel's conception of trust as well as Hardin's.

Horizontal trust between legal officials is intermediate between trust in particular individuals and generalized social trust in the reliability of people in general. It is wider than trust in particular individuals because it concerns the attitude of individual officials toward other legal officials as a group. But it is not entirely generalized in that one might trust other officials to follow the law without in any way trusting their general moral judgment or their character in their personal lives. Likewise, one might trust other officials to follow the law while distrusting people in general. In short, the sort of trust at issue here exists within a particular domain and a particular group of people but does not require a personal relationship between the trusting party and the trusted parties beyond their participation in a common institution.

My argument concerns the behaviour of legal officials. A legal official is an agent of the state who is charged with interpreting and applying the law. Judges are the most prominent type of legal official. However, legal officials also include prosecutors, government lawyers, executive branch officials, and various employees of government agencies. Legal officials consult legal sources and act on their interpretations of these materials. They have some degree of discretion when acting in their official capacity in interpreting and applying the law. Of course, most legal officials operate within a hierarchy in which higher-level officials may review the determinations of lower level officials and countermand their orders on this basis. At the lowest levels of such hierarchies, officials are not expected to exercise much personal judgment about what the law requires and instead follow directives from their superiors. At higher levels a greater degree of personal judgement is often required. 
For ease of presentation, I will often speak as if what the law requires is either relatively determinate, in which case legal officials must decide whether to apply the law, or indeterminate, in which case they may act on non-legal considerations. This is an oversimplification. Legal determinacy is not all or nothing. There are cases in which some answers seem legally better than others but it may not be entirely clear which answer is correct. For example, a common law judge might be faced with a case in which no prior case is wholly analogous and the nearest precedents point in opposite directions. In such instances, the legally correct decision will depend on how to understand the rule set out in these cases and on which precedents are most similar to the facts of the instant case. Because reasonable minds might differ as to how to weigh conflicting considerations, it might be better to speak of some answers being legally better than others without one being definitively correct and the others incorrect. A given case could be resolved in many different ways with $\mathrm{A}, \mathrm{B}, \mathrm{C}, \mathrm{D}$, and $\mathrm{E}$ each being a ruling with supporting legal reasoning. I might prefer A, but count B and C as legally plausible answers that another competent lawyer might reach in good faith while thinking that $\mathrm{D}$ and $\mathrm{E}$ could only result from mistake, bias, or bad faith. This might well be the case even if A and D require a judgment for the plaintiff and $\mathrm{B}, \mathrm{C}$ and $\mathrm{E}$ require a judgment for the defendant. Agreement on outcome is therefore neither necessary nor sufficient for recognition that another person has reached a reasonable result while acting in good faith. For the purposes of this argument, what is most important is whether a legal judgment is good enough to count as a good faith attempt to get the law right rather than whether it is the best possible answer supported by the most compelling reasoning.

\section{The Rule of Law as Convention}

The rule of law depends on a convention that officials apply the law when the law directs them to do so rather than issuing directives and resolving disputes on some other ground. By this I mean that in situation type $\mathrm{S}_{1}$, legal officials prefer to follow the law if other 
officials follow the law in situation type $S_{1}$ but would follow some other rule if others do not apply the law in situation type $S_{1}$. There are many reasons that an official might do A when the law requires $\mathrm{B}$. The official might believe that the balance of non-legal moral considerations weighs in favour of not following the law. ${ }^{6}$ The official might have reasons of self-interest, which could include anything from sheer laziness to out-and-out corruption, not to follow the law. The official might wish to seek favour with political authorities that prefer some result other than the legally prescribed one. Some of these considerations may be objectionable for reasons having nothing to do with the rule of law. But others may be morally weighty. A morally conscientious official will, from time to time, find that her private views about what is morally preferable diverge from the law.

Legal officials might take a range of attitudes toward the law. To simplify a bit, I will consider three types of general attitudes. An official who is faithful to the law makes a good faith attempt to determine what the law instructs her to do and treats this as a weighty, although defeasible, reason to act according to the law. The faithful official will typically apply the law as she perceives it regardless of external incentives to do so and will sometimes apply the law when it reaches results that differ from her all-things-considered moral judgment about the right result. When faced with a difficult legal question, she will go to great lengths to determine

\footnotetext{
${ }^{6}$ For purposes of exposition, I put my argument in terms that suggest a positivist view of the law. More specifically, I appeal to a distinction between legal reasons and non-legal moral reasons for action. Legal positivism is the view that whether a norm is legally valid depends on its sources and not on its merits (Gardner 2001, 199). In other words, whether a given rule is part of the law depends on whether it has been created according to the rules of the legal system and not on whether it is morally desirable. This leaves open the question of whether the law might sometimes require legal officials to exercise their moral judgment by incorporating moral standards and the question of whether legal officials morally ought to follow the law when the law gives directives that conflict with the official's own moral judgment. It is possible that my argument could be reconstructed in anti-positivist terms, although I will not attempt to do so here. For Dworkinians, all types of moral considerations could, in principle, be relevant to the ways in which legal materials create legal content (Dworkin 1986). It is less clear for Dworkinians than for positivists, therefore, whether a given normative consideration gives rise to legal reasons or non-legal moral reasons.
} 
the proper legal result before concluding that the legal materials are indeterminate and that she must therefore rely on her own judgment. Even here, the faithful official will try to reach a result that coheres well with the rest of the law.

Of course, even legal officials who are committed to faithfully applying the law should deviate from the law in some circumstances. Following the law regardless of all other considerations is a sort of moral fanaticism. There are circumstances, even in basically just and decent legal systems, in which the prima facie obligation to apply the law is outweighed by other moral considerations. I do not wish to explore the issue of how wide or narrow this set of circumstances is. It suffices to say that if such circumstances are construed too broadly, they will undermine the convention that legal officials follow the law and so there must be some non-trivial range of circumstances in which the obligation to apply the law faithfully outweighs countervailing non-legal moral considerations.

A second type of official is the legal cynic. The legal cynic cares about the content of the law, but for purely instrumental reasons. The legal cynic is concerned to avoid sanction and perhaps to advance his career and will apply the law when necessary to achieve these ends. The legal cynic lacks, however, any internal motivation to determine the correct legal result or to apply the law faithfully. If he feels reasonably certain that he will not be sanctioned for failing to apply the law, he may make decisions on other grounds. The legal cynic may be public-spirited, self-interested or some combination of the two. The cynic might be a careerist, concerned to receive good job evaluations, curry favour with political authorities or receive recognition for legal acumen. But the legal cynic might instead be someone genuinely motivated to do the most good in the world who does not see the law as a means to achieving that end. This sort of cynic may have prudential reasons to follow the law since ignoring the law entirely could result in him being dismissed, demoted, sanctioned or distrusted by his superiors and thus frustrate his ability to achieve his goals. Of course, being this sort of legal 
cynic might be an entirely appropriate response to a legal system that does not, in general, promote morally good ends.

A third sort of official is the legal nihilist. ${ }^{7}$ The legal nihilist is like the legal cynic in having no intrinsic motivation to apply the law, but goes beyond this by ignoring the law altogether. This could be because the legal nihilist is sceptical that the law has any sort of determinant content whatsoever and therefore cannot require any particular result. Or the legal nihilist might believe that it makes no difference whether one applies the law or not. The legal nihilist might, for example, try to reach results that will please her superiors regardless of whether they are legal. Or perhaps she is committed to resolving disputes according to her broader moral views and finds that the law is simply irrelevant in working out what the best thing to do is. Legal nihilists may differ greatly from one another. The key commonality is that they only follow the law by coincidence.

All three types may exist within a single legal system. In general, the more faithful officials and the fewer legal nihilists in a legal system, the better it will function. The role of legal cynics is context dependent. In a system with many faithful officials, legal cynics are less likely to create trouble, as the cynics will be more likely to see themselves as having prudential reasons to apply the law. In a system with many legal nihilists, however, the cynics are less likely to apply the law since they will believe that reputational benefits for doing so are minimal and sanctions for failing to do so are unlikely. In a legal system with a mix of types, the behaviour of legal cynics will depend in large part on how well they can be monitored and sanctioned. The presence of legal cynics stresses the legal system. Strong institutions can withstand a certain amount of stress. Too much stress will cause them to break down.

7 The label is inspired by Russian Prime Minister Dmitri Medvedev, a corporate lawyer by training, who complained a decade ago that Russia was a land of "legal nihilism" (Smolchenko 2008, 1). 
Dividing officials into ideal types is an oversimplification. The same officials might act as a faithful official in one context but not in another. For example, an official might faithfully apply the law in domains that seem morally defensible as a whole, but act as a legal cynic in a domain where the law seems morally perverse. More importantly, the behaviour of legal officials might depend on their expectations about the behaviour of other parties in the legal system. An official might act as a faithful official if she expects others to do so, but behave as a legal cynic if she perceives other officials as cynics or nihilists. In many cases this is perfectly reasonable.

A central function of law is to solve coordination problems for agents who have an interest in coordinating their actions with those of others but have difficulty in doing so when making choices individually. The law does this by guiding action, for example by requiring that drivers drive on the left side of the road rather than the right, and by prescribing punishment for those who break the rules. The latter is especially important in situations in which conventions are not self-enforcing and so establishing a rule is not sufficient to resolve the coordination problem. Many of the benefits of rule by law are only available if the law is applied at least somewhat regularly. The law cannot provide certainty or predictability if officials routinely ignore it. Legal subjects who realize that officials do not apply the law are unlikely to use the law to guide their own behaviour. Rule by law is therefore a collective action problem. There are systemic benefits to using law to guide the behaviour of legal officials but each official has their own competing non-legal reasons for action.

For morally responsible officials, applying the law is not a pure coordination convention. A pure coordination convention is one such as the convention to drive on the left side of the road in which agents are indifferent as to which rule to follow and care only that all follow the same rule. The rule of law is not like this. In a minimally decent legal system it is better that officials follow the law than that they act on non-legal reasons. So while the morally 
responsible official might look to whether other officials apply the law when deciding whether to apply the law herself, she will prefer the world in which all officials follow the law to the world in which no officials follow the law. In a system populated mainly by officials who prefer to follow the law if others do so as well, following the law will be a stable equilibrium. Of course, faithful officials faced with an environment in which few officials follow the law cannot simply will their way to the better equilibrium. It may be unwise for legal officials to apply the law in the face of non-legal reasons not to do so absent a belief that other officials behave similarly. There is little to be gained by being one of a few faithful officials in a legal system but much to be gained by having an entire legal system staffed by faithful officials.

In game theoretical terms, the situation faced by officials who value the rule of law resembles a stag hunt (See Skyrms 2012). In an example first introduced by Rousseau (1997, 163), hunters may either hunt stag together, which will only be successful if all hunters participate, or hunt hare individually, which each individual hunter can successfully do alone. The payoff for a successful stag hunt is greater than the payoff for a successful hare hunt. All hunters will do better if all cooperate in hunting stag together, but if some do not cooperate, the rest will do better to hunt hare alone. So if the hunters expect their fellows to do their part in the stag hunt, they should do so as well, but if they expect some other hunters to go after hare while letting the stag escape, they should hunt hare. Matters are more complex if the question of whether officials are to follow the law is more like a prisoner's dilemma. In this case, each official prefers to follow her own moral views when they conflict with the law but prefers that other officials faithfully follow the law. The officials prefer the state of the world in which all officials follow the law to that in which no officials follow the law. But left to their own devices, they will each rule according to their own moral views. In this case, some mechanism may be necessary to sanction officials who do not faithfully apply the law so as to shift the motivations of officials. This will tend to shift the strategic situation from a prisoner's 
dilemma to the stag hunt. Sanctions are less important if legal officials are intrinsically motivated to promote the rule of law. One benefit of a legal culture with a strong commitment to the rule of law is that legal officials who intrinsically care about the rule of law are more likely to see themselves as in a stag hunt than in a prisoner's dilemma and therefore more likely to follow the law so long as they expect others to do so as well. ${ }^{8}$

If the foregoing analysis is correct, the attitude that a legal official takes toward the law will depend in part on their expectations about the behaviour of other officials in the legal system. Legal officials are not likely to apply the law for its own sake unless they believe that other officials apply the law with a certain degree of frequency. Trust in the good faith of other officials in the legal system is therefore of great importance. This will depend both on whether officials perceive others to be applying the law impartially and on whether officials trust the moral and prudential judgment of other officials. High trust in other officials encourages faithful application of the law, which in turn encourages these other officials to follow the law. High trust and high compliance with the law is therefore likely to be a stable equilibrium while low trust and low compliance is also likely to be stable. Partner choice over repeated interactions is sometimes effective in spreading pro-social norms (Baumard, Andre, and Sperber 2013). But legal officials typically do not have control over which officials they will interact with. Oversight by faithful officials may push cynical officials to follow the law, but in a low trust environment, unlawful conduct may be so common that sanctions cannot be deployed against enough officials to change the legal culture. ${ }^{9}$ This might go some way to

\footnotetext{
${ }^{8}$ Once the parties have committed to following some legal rule, the strategic situation may shift to a partial conflict coordination game, sometimes known as "The Battle of the Sexes," in which two parties prefer to agree on some outcome, but disagree on which of two preferable outcomes is preferable (Waldron 1999, 103-104; Gaus 2011, 458). This differs from a stag hunt because each party prefers agreement to disagreement under all circumstances.

${ }^{9}$ In some cases, the best option may be to dismiss officials en masse and start over. To take an extreme example, the Republic of Georgia was without traffic police for several months in 2004 while new officers were trained after the government fired all traffic police (Light 2014, $325)$.
} 
explaining why some governments seem remarkably law abiding while others seem pervasively lawless despite superficially similar laws and institutional arrangements.

Perceptions of fellow officials are of great importance. For several reasons, whether officials are making a good faith effort to follow the law is only partially observable. First, officials have limited time to monitor the behaviour of other officials, especially those for whom they have no formal responsibilities. Second, legal officials are not always candid about the true reasons for their actions. A skilful lawyer can often find an explanation for a dubious decision that has at least a surface level of plausibility, especially to those who have not carefully studied the underlying legal materials. Even in well-functioning legal systems, judges sometimes give pretextual reasons for their decisions (Kolber 2018). Shrewd cynics and nihilists will usually find ways to cloak their actions so as not to appear too egregious. Faithful officials will also be inclined to offer pretextual reasons for their decisions in those rare cases in which they deviate from what the law requires in order to protect the reputation of the legal system. Third, it can be difficult to distinguish good faith mistakes from officials who are in some sense not really trying to get the law right. This is especially so where the law is not clear or where the facts are complex. Fourth, faithful officials might have reasonable disagreements about whether a particular case is one in which officials ought to deviate from what the law requires. ${ }^{10}$

All of this suggests that officials have imperfect information about the extent to which others are attempting to follow the law faithfully and are not able to signal such a disposition to each other with perfect clarity. Officials will tend to conclude that other officials are

\footnotetext{
${ }^{10}$ Some judges take their jobs to be primarily to resolve disputes in a manner that is fair to litigants and provide appropriate incentives for future conduct rather than to apply a body of pre-existing legal rules. For example, Judge Richard Posner described his own method of judging by saying that "I pay very little attention to legal rules, statutes, constitutional provisions ... A case is just a dispute. The first thing you do is ask yourself-forget about the law-what is a sensible resolution of this dispute?" (Liptak 2017).
} 
applying the law faithfully insofar as that they agree with their legal judgments, find that they give plausible reasons for their legal conclusions and do not appear to overstep their authority. Because legal officials have only limited insight into the motives of other officials and may have different conceptions of the scope of reasonable disagreement between faithful officials, significant disagreement about legal outcomes tends to lower trust between officials. Disagreement in legal judgment among officials thus discourages faithful application of the law and tempts officials to give legal explanations that do not reflect their underlying reasoning.

An implication of this argument is that agreement on the content of the law among legal officials is desirable for reasons that do not depend on agreement being a sign of correctness. Of course, this is not the only reason to care about agreement on legal results. Convergence in legal judgment is often evidence of moral merit. And convergence in judgment makes legal systems more efficacious in guiding the action of legal subjects and resolving disputes in a predictable and expeditious manner. Promoting agreement between legal officials is only one virtue of a legal rule and must be weighed against other considerations. "Always find for Defendant against Plaintiff" is a rule that is simple to apply and could, in principle, generate universal agreement on the correct outcome of civil cases. But because it is entirely divorced from the point of having civil adjudication at all, it is a non-starter as a decision rule. It is selfundermining, because the sheer irrationality of the rule would encourage officials to find pretexts to avoid situations in which it should be applied or to ignore the rule altogether. Agreement should therefore be a criterion to decide between legal norms that are otherwise plausible on other grounds, especially when there do not otherwise appear to be decisive considerations to distinguish between them. As will be argued later, theories of statutory interpretation provide a plausible example.

To summarize, legal officials often face situations in which they must choose between applying the law and pursuing other objectives. For many officials, willingness to apply the 
law depends on their expectations of other officials in the legal system. Trust in the lawful conduct of other officials makes faithful application of the laws more likely which in turn reinforces trust. Distrust encourages a cynical approach to the law, which spreads distrust. This means that it is of great importance to achieve and maintain a high trust equilibrium in the legal system. Faithfulness to the law is only partially observable. Legal officials are likely to take agreement with their legal judgment as strong evidence of faithfulness to the law. This gives us reason to prefer legal rules that tend to create convergence in judgment between officials to rules that lead to disagreement between officials aside from any epistemic value of agreement. In other words, it is good for legal officials to agree about how to apply the law apart from whether their judgment converges on the best result.

\section{Building Trust between Legal Officials}

The foregoing argument suggests that trust between legal officials is important to a well-functioning legal system. A low trust legal system will necessarily rely more heavily on monitoring and incentives for good legal performance. Such legal systems can function well if they are carefully designed and well administered. All else equal, however, a high trust legal system will both be more effective, efficient, and stable. Low trust systems are at greater risk of unravelling if the threat of sanctions becomes insufficient to motivate officials or if the system of sanctioning becomes too capricious because the higher level officials administering it are insufficiently concerned with fidelity to the law as opposed to disciplining officials who displease them for other reasons.

A high trust legal system has other benefits as well. Judges in a high trust system are more likely to be transparent about the true reasons for their decisions and less likely to make rulings on pretextual grounds or otherwise obfuscate the reasons for their decisions. Appellate tribunals are more likely to defer to fact-finders if they believe that the fact-finders' determinations are based on a good faith effort to get things right and that the reasons they give 
in their rulings reflect the actual reasons for their decisions. The law in a high trust system is more likely to be stable and thus more likely to be predictable. And a high trust system is more likely to respond effectively to changing circumstances because the officials in the system will find it easier to coordinate on responses that all accept as authoritative.

Social trust is important to the rule of law in a second way. In a complex legal system, convergence on shared understandings of how to apply the law to particular facts depends on shared understandings about how to translate legal materials-statutes, case law, administrative regulation and so on-into legal content. Some such understandings are based on formal constitutional or statutory rules, such as the rule that the U.S. Constitution is superior to other sources of law. Others emerge from judicial practice. A great deal of interpretive work is done by informal rules, sometimes called canons of statutory interpretation that judges use to resolve difficult interpretive questions (Baude and Sachs 2017). For example, the canon against surplusage provides that when considering two interpretations, one should prefer an interpretation that renders all words necessary to the meaning of the statute to an interpretation that renders some words duplicative or superfluous (Scalia and Garner 2012, 440). Canons help judges to agree on interpretations of ambiguous statutes and give prospective guidance to legislatures about how their legislation will be construed by courts. ${ }^{11}$ Will Baude and Steve Sachs $(2017,1084)$ argue that canons can be divided into linguistic canons that reflect standard linguistic practice and legal canons that are rules of a legal system. The former are useful for interpretation of both legal and non-legal texts since they reflect the practices of typical writers in a given language while the latter might well violate rules of standard English usage and are in fact a substantive law of interpretation created by judges. What counts as a canon is dependent on what judges accept as a canon. As Victoria Nourse and Anita Krishnakumar

${ }^{11}$ This guidance is imperfect. Surveys of congressional staff responsible for legislative drafting show that staff are aware of only some of the canons cited by judges (Gluck and Bressman 2013, 933-36). 
(2018, 188) argue, "the basic thread connecting the canons is (or should be) established convention. Longevity or historical pedigree, and perhaps a connection to the Constitution, can help demonstrate established convention, but . . . the real, indispensable measure for such convention must be regular Supreme Court use across ideological divides." The disposition to accept rules adopted by one's ideological opponents depends in part on trust that one's opponents will apply the rules fairly when they go against their preferred outcomes. Trust across ideological lines is therefore important in creating the tacit understandings that make legal interpretation more stable.

Various features of the design of legal systems and the substance of legal doctrine serve to minimize the scope for disagreement on potentially controversial interpretive questions. I will discuss two. One strategy to conserve trust in the legal system is to make procedure the primary focus of legal rules and delegate context-specific factual judgments and decisions on controversial normative matters to decision-makers with somewhat narrow institutional roles. For example, a wide range of questions in civil and criminal trials are delegated to unaccountable juries (or trial judges) whereas appeals courts largely review whether the trial court has followed the proper procedure. As a result, the substance of appellate cases in the U.S. legal system focuses very heavily on procedural matters such as jurisdiction and rules of evidence. This focuses appellate judges on legal questions concerning fair procedures about which there is more likely to be broad agreement on most underlying normative principles. This division of labour might be dubious from an epistemic point of view as it puts important decisions in the hands of lay jurors who may not be especially well prepared to sort through complex fact patterns involving complicated business transactions or intricate financial frauds. By contrast, appellate judges are typically asked to consider not whether a defendant is guilty or not guilty or whether a defendant's conduct was reasonable or unreasonable but only whether a reasonable jury might have found it so. In theory at least, this means that the most 
difficult questions in these areas should be left to juries and trial judges while appellate judges decide only whether the lower court's decision fell below the threshold of reasonable disagreement. $^{12}$

Similarly, judicial review of administrative action focuses heavily on procedural questions. Administrative agencies are given considerable discretion to make substantive decisions so long as they follow the proper procedures and do not exceed their statutory authority. As with jurors, judges are typically asked to decide whether agency action has gone too far rather than whether the action was, all things considered, the best thing to do. When substantive matters are considered, they are often done in a way that is deferential to the initial decision-maker such as when agency decisions are reviewed under the arbitrary and capricious standard (Administrative Procedure Act, 5 U.S.C. $§ 706(2)(A)$ ) or when agency interpretations of statutes are given deference under Chevron v. Natural Resources Defense Council, 467 U.S. 837 (1984). Part of the justification of Chevron is clearly epistemic: agencies receive deference in areas in which they are expert as long as they stay within the scope of plausible interpretations of a statute. But a side effect of this approach is that it potentially removes a number of politically controversial interpretive questions from the remit of appellate courts by adopting a "tie goes to the agency" approach to hard interpretive questions. ${ }^{13}$ Of course, heated disagreement might still emerge when considering whether an agency's decision is based on a permissible construction of the statute. But here the inquiry is whether the agency has given a plausible reading, not whether it has given the best one. The approach may tend to diminish

12 In practice, judicial discomfort with delegating decisions to juries in certain contexts sometimes leads judges to try to avoid sending cases to trial or to take a more active role in policing the outcome of jury deliberations than might be expected from a straightforward reading of the doctrine.

13 This justification is controversial. For example, Justice Kavanaugh (2016, 2137-2138) argues that Chevron generates uncertainty because judges have different standards for how ambiguous a statute must be before deference is required with some judges treating 90-10 issues as ambiguous while other require that an issue be closer than 65-35. 
vertical trust by making administrative agencies less accountable, but increase horizontal trust since it spares judges the necessity of reaching agreement on a significant class of hard legal questions.

A second strategy for building horizontal trust is to design rules for the selection, training, and promotion of legal officials that inculcate shared understandings about the law. This is most easily done by maintaining a professional staff of legal officials who work within the same system for an entire career. Such officials would receive similar educations, which would provide them with a similar knowledge base, inculcate similar cultural norms, and allow future officials to develop social relationships with one another. They would be subject to similar standards for hiring and promotion and would play the leading role in evaluating each other's work. In many nations, although not in the United States, judges are selected at a relatively young age and hired into a meritocratic bureaucracy, in which the most esteemed judges are promoted from the lowest level courts to high level courts over the course of their career. Commonality of experience and strong career incentives to appear favourably in the eyes of other judges probably contribute to higher levels of horizontal trust. But there is an important trade-off here. The very factors that build trust between members of the legal system tend to make it unrepresentative of the larger population and poorly responsive to public sentiment. For this reason, there is a danger that institutions that build horizontal trust may undermine vertical trust.

\section{Trust and Statutory Interpretation}

The first part of the argument has established that trust between legal officials is important to the rule of law and that agreement between officials is valuable in that it enhances trust. This section will explore some implications of this conclusion for debates about legal methodology. I will argue that the desideratum of agreement between legal officials can be used in selecting methods of statutory interpretation. This is an unusual approach. More 
typical approaches to interpretive methodology usually involve (a) arguing that a methodology captures the meaning of statutes better than its rivals (Katzmann 2014, 4-5), (b) arguing that a methodology captures the intentions of the legislature better than its rivals (Fallon 2014, 686), or (c) identifying some extrinsic value such as democratic legitimacy, legislative supremacy or transparency to the public and argue that the methodology better serves this end (Dworkin 1986). My argument is most similar to the third approach, but rather than being grounded in an expensive conception of the moral aims of law, appeals only to a fairly minimal conception of the rule of law. This minimal conception depends only on the proposition that it is better for legal officials to apply the law for its own sake absent unusually strong moral considerations to the contrary. For this reason, it might find support from people who have deep disagreements about other aspects of legal methodology.

There is a long running debate between proponents of textualist and purposivist approaches to statutory interpretation. How to define these terms is controversial. In general, textualists prefer interpretation in terms of plain meaning, oppose consultation of legislative history, and prefer to resolve ambiguities through use of canons of interpretation rather than speculation about legislative motives. Purposivist interpretation construes statutory language in light of the purposes that might reasonably be attributed to the legislature. In a classic statement of the "legal process theory" of statutory interpretation, Henry Hart and Albert Sacks $(1994,1374)$ argue that

[I]n interpreting a statute a court should: 1 . Decide what purpose ought to be attributed to the statute and to any subordinate provision of it which may be involved; and then 2. Interpret the words of the statute immediately in question so as to carry out the purpose as best it can, making sure, however, that it does not give the words either - (a) a meaning they will not bear, of (b) a meaning which would violate any established policy of clear statement.

The gist of this is that the plain meaning of statutory terms is a constraint on permissible interpretations, but when choosing between plausible interpretations, courts should prefer an interpretation that coheres with the overall aims of the statute even if that interpretation might 
seem less preferable on purely linguistic grounds. Textualists disagree. John Manning (2006, 110) suggests, "textualism means that in resolving ambiguity, interpreters should give precedence to semantic context (evidence about the way reasonable people use words) rather than policy context (evidence about the way reasonable people would solve problems)." Caleb Nelson $(2005,351)$ argues that underlying this difference is a preference for rules on the part of textualists and for standards on the part of purposivists. In other words, textualists prefer bright line rules applied in a somewhat formalistic way whereas purposivists prefer standards that are more open-ended.

There is a vast literature on the advantages and disadvantages of each approach. Textualists tend to suggest that their approach is preferable on the one hand in placing greater constraints on judges who might be inclined to read their only policy preferences into the law and on the other in making the law more understandable and predictable for citizens trying to understand their legal position by reading statutes (Scalia and Garner 2012, xxviii, xxix). Arguments for textualism range from the claim that purposivist judging usurps the role of the legislature (Manning 1997), the argument that judges are better positioned to apply textualist than purposivist methodology (Vermeule 1998), and the argument that purposivist method undermines that rule of law by making the meaning of statutes opaque for citizens attempting to determine their rights and duties (Scalia 1989). Purposivists suggest that textualist methodology tends to frustrate the aims of legislatures (Eskridge 2013, 560-567), is apt to be unworkable in the sort of hard cases in which interpretive methodology is likely to be important (Eskridge 2013, 583-587), and deprives judges of valuable contextual information such as legislative history (Katzmann 2014, 35-39). I will not try to resolve this debate. Instead, I would like to suggest that different methodological approaches may be appropriate in different 
areas of the law ${ }^{14}$ and that the importance of agreement on legal outcomes can help to determine which approach is more appropriate in a given context.

Does textualist methodology lead to greater convergence among interpreters on the content and proper application of the law or does purposive methodology generate greater agreement? There are things to be said in favour of each view. ${ }^{15}$ Textualists might point to the way in which their methodology restricts the scope of considerations that can be brought to bear on statutory interpretation. This both limits the extent that judges can appeal to normatively controversial purposes and the extent to which they can "cherry pick" favourable legislative history. Purposivists might argue that textualism fares poorly when confronted with ambiguous texts and needlessly produces hard cases by removing some of the tools judges might use to resolve ambiguities. Moreover, the canons of interpretation that textualists believe should resolve ambiguities sometimes yield unequivocal or even contradictory results (Llewellyn 1950, 399).

The extent to which textualism or purposivism leads to greater agreement on the content of the law is likely to be domain specific. In areas in which there is broad agreement on the background normative considerations, purposivism may have an advantage. In such areas, legal interpreters are likely to have similar intuitions about the ways to interpret provisions in light of the underlying aims of the statute. ${ }^{16}$ It also is more likely to be the case that the statute in question reflects a normatively coherent perspective rather than an unprincipled compromise between mutually inconsistent viewpoints. Purposive considerations and policy reasoning

\footnotetext{
${ }^{14}$ Frederick Schauer $(1988,547)$ has made a similar suggestion about the role of formalism in the legal system.

${ }^{15}$ Skeptics doubt that differences in theoretical approaches to statutory interpretation have any large influence on results. For example, an empirical study by Frank Cross (2007, 1991-95) found that convergence upon textualist and purposivist methodologies does not lead to consensus among judges about case outcomes.

${ }^{16}$ For a perceptive discussion of the role of intuition in legal judgment, see Crowe $(2019,77$ $84)$.
} 
more generally can help interpreters to come to similar conclusions even when the text is semantically or syntactically ambiguous or when different parts of the same statute appear to have different implications.

Where there is broad agreement on the background objectives of the law, legal officials should develop shared understandings about the ways in which laws are to be interpreted in this domain. This is not a suggestion that judges develop shared understandings that undermine the values implicit in the relevant statutory schemes. The idea is that where the shared understandings are consistent with the statutory scheme, they might render more purposive interpretation appropriate. I want to remain neutral about whether the norms governing interpretation in a given legal system are a part of a law of that legal system or merely a set of extra-legal conventions concerning the extraction of legal content from legal materials. It may be that some fall into the former category and some in the latter (Baude and Sachs 2017, 1084). The key point is that these norms should be crafted in part with an eye toward helping legal officials to converge on the same interpretation of legal materials.

Matters are different when there is deep normative disagreement about the relevant policy considerations. Here, interpreters are likely to have different intuitive reactions to the way in which purposes have bearing on the meaning of a statute. Of course, judges are capable of interpreting statutes in light of purposes that they find normatively objectionable. But it is generally much easier to reason from a position with which one agrees than from one with which one disagrees. And it is easier to imaginatively reconstruct the intentions of parties whose aims one broadly shares. When there is pervasive underlying normative disagreement, it may be advantageous to restrict interpreters to consideration of purposes found on the face of the statute. Although textual considerations may not always be decisive, in normatively contested areas of law they will tend to be less divisive than purposive considerations. A 
formalistic approach to statutory interpretation can be useful precisely where more open-ended inquiry is likely to leave judges with differing ideologies at loggerheads.

Income tax law provides an example of the first type of case. Although tax law is based on a voluminous statutory code reinforced by an even larger number of regulations, it is an area in which agreement on the underlying policy animating much of the code can help to resolve statutory ambiguities. The underlying idea is that as Lord McNaughton once put it, "an income tax is ... a tax on income" (London CC v Attorney General [1901] A.C. 26 HL, 35). In light of this aim, the tax code should be interpreted to the extent possible such that tax is imposed on all and only those items that are the taxpayer's income from an economic point of view. This does not resolve all possible ambiguities because there are still hard cases that turn on whether a receipt is an item of income or not or if so whether it is income to the taxpayer or to some other party. But it does give us reason to prefer interpretations that make sense in light of economic substance to ones that would cause tax treatment to deviate from the underlying economic reality. To illustrate the differences in possible approaches, consider a pair of cases from around the same time in the United States and United Kingdom. In Gregory v Helvering, 293 U.S. 465 (1935), Evelyn Gregory owned shares in a company, United Mortgage Holdings ("United") that held 1,000 shares of Monitor Securities Corporation ("Monitor"). If United sold the shares of Monitor and distributed the proceeds to Gregory, the amount distributed would be taxed as a dividend. Instead, Gregory, formed a new corporation, Averill, and transferred the Monitor shares to Averill. She then liquidated Averill, distributed the Monitor shares to herself, sold the Monitor shares, and claimed the proceeds to be taxable as a capital gain (Gregory v. Helvering, 467). Gregory claimed that the transaction was a "'reorganization" under section 112(g) of the Revenue Act of 1928" (Gregory v Helvering, 467). Although Gregory's transaction seemed to fall under the literal meaning of section 112(g) insofar as she was in control of both the transferring corporation and the recipient corporation, the U.S. 
Supreme Court, affirming a Second Circuit Court of Appeals opinion authored by Judge Learned Hard, (Helvering v. Gregory, 69 F.2d 809 (1934)), ruled that Gregory should be taxed as if she were paid a dividend by United. As Justice Sutherland put it, Gregory's transaction was "an operation having no business or corporate purpose ... [the] accomplishment of which was the consummation of a preconceived plan, not to reorganize a business or any part of a business, but to transfer a parcel of corporate shares to the petitioner." (Gregory v Helvering, 469). The upshot of this approach is that courts should consider the economic substance of a transaction in light of the purpose of the relevant statutory provision and not necessarily uphold transactions merely because they take a form that plausibly falls within the meaning of a formalistic interpretation of the statutory language.

The UK approach at this time was quite different. In IRC v Duke of Westminster [1936] AC 1, the Duke of Westminster signed covenants to provide annuities to several long-time servants. In a separate letter, the Duke's solicitor explained that the servants would be expected to accept a wage reduced by the amount of the annuity. However, there was no obligation for the servants to stay in the Duke's employment in order to receive the annuity. Under UK law at the time, an annuity was generally income of the recipient for tax purposes and could be set against the payer's taxable income. Wages paid to personal servants, however, could not be set against the employer's taxable income. The Duke, an extraordinarily wealthy aristocrat taxed at a very high marginal rate, claimed that he should not be taxed on the value of annuities. The Commissioners of Inland Revenue disagreed. A divided House of Lords held that the Duke was not liable for tax on the annuities. The majority emphatically rejected the notion that taxation should follow the economic substance of the transaction. Lord Russell of Killowen stated, "I view with disfavour the doctrine that in taxation cases the subject is to be taxed if, in accordance with a Court's view of what it considers the substance of the transaction, the Court thinks that the case falls within the contemplation or spirit of the statute. The subject 
is not taxable by inference or by analogy, but only by the plain words of a statute applicable to the facts and circumstances of his case." (IRC v Duke of Westminster, 24).

The reasoning in Gregory v. Helvering, if applied to the facts of the Duke of Westminster, would make for an easier case. Here, the formalistic approach-asking whether the annuity is a separate agreement from the employment agreement—leads to a close case, whereas the appeal to economic substance considered in light of the purposes of the statuteasking whether the Duke enjoyed the benefit of the income or was simply making a disinterested gift-yields a more determinate result. Although matters may not have been so when Duke of Westminster was decided, there is now broad agreement that income taxes should be imposed on economic income enjoyed by the taxpayer to the extent that this is administratively feasible. ${ }^{17}$ This agreement tends to cut across ideological lines, including, for example, supporters and opponents of progressive taxation. In this way, overarching policy considerations can help interpreters agree on how to apply the technical provisions of the tax code to complex fact patterns.

By contrast, textualism seems better able to promote agreement in areas in which there is deep normative disagreement on the relative underlying policy considerations and where purposivist methodology is likely to push interpreters with different ideological perspectives apart. This suggests that textualist approaches should be preferred in areas such as constitutional law in which there is deep disagreement about foundational normative matters. Which areas are ideological flashpoints varies by legal system and varies over time within a single legal system. In general, areas of regulatory law that balance competing considerations, environmental protection and economic growth for example, are more likely to be sites of normative discord than areas, (antitrust might be such an area), in which disagreement centres

${ }^{17}$ UK tax law has also moved away from the Duke of Westminster approach in the direction of Gregory v. Helvering, although it is fair to say that it remains more formalistic than the U.S. approach to tax law. 
more on means than on ends. In the former areas, a more formal approach to statutory interpretation might yield as much agreement as possible given the underlying ideological tensions. ${ }^{18}$

\section{Conclusion}

In order for the legal system to function effectively, officials must sometimes apply the law because it is the law. Their disposition to do so depends in part upon trust in other officials to act similarly. Disagreement over the content and proper application of legal rules tends to undermine trust between officials and thus their motivation to follow the law. For this reason, promoting convergence in judgment should be an aim of legal methodology even aside from any reason to think that this convergence of judgment tracks substantively desirable results. For hard issues, such as the best approach to statutory interpretation, the question of which method best promotes convergence in judgment can be used to choose legal methodology where other considerations are equivocal or too controversial to secure broad agreement. Purposivism is generally a better tool for securing agreement about how to construe ambiguous passages in statutes where there is rough normative consensus about the higher-level considerations of policy. Textualism is typically more attractive when there is deep disagreement about the background normative principles. The appropriate balance between the two approaches will vary across legal systems. Which methods promote convergence in legal judgment depends both on the institutional design and culture of a legal system and on broader social and political factors. Conventions are often path dependent and every legal system must work out its own common understandings.

${ }^{18}$ Similar considerations might count in favor of the plain meaning rule (Schauer, 1990, 23132; Schauer 1992, 724). 


\section{References}

Baude, William and Stephen E Sachs. "The Law of Interpretation." Harvard Law Review 130, no. 4 (February 2017): 1079-1147.

Baumard, Nicolas, Jean-Baptiste Andre, and Dan Sperber. "A Mutualistic Approach to Morality: the Evolution of Fairness by Partner Choice." Behavioral and Brain Sciences 36, no. 1 (February 2013): 59-78.

Becker, Lawrence C. “Trust as Non-Cognitive Security about Motives.” Ethics 107, no. 1 (1996): 43-61.

Bergh, Andreas, Christian Bjørnskov, and Kevin Vallier. "Social and Legal Trust: The Case of Africa." in Social Trust, edited by Kevin Vallier and Michael Weber, Routledge, 2021.

Cross, Frank B. "The Significance of Statutory Interpretive Methodologies." Notre Dame Law Review 82 (2007): 1971-2004.

Crowe, Jonathan. "Not-So-Easy Cases." Statute Law Review 40, no. 1 (February 2019): 7586.

Domenicucci, Jacopo and Richard Holton, "Trust as a Two-Place Relation.” in The Philosophy of Trust, edited by Paul Faulkner and Thomas Simpson, 149-160. Oxford: Oxford University Press, 2017.

Dworkin, Ronald. Law's Empire. Cambridge: Harvard University Press, 1986.

Eskridge Jr., William N. "The New Textualism and Normative Canons." Review of Reading Law: The Interpretation Of Legal Texts, by Antonin Scalia \& Bryan A Garner. Columbia Law Review 113 (2013): 531-592.

Fallon Jr., Richard H. "Three Symmetries between Textualist and Purposivist Theories of Statutory Interpretation - and the Irreducible Roles of Values and Judgment within Both." Cornell Law Review 99, no. 4 (May 2014): 685-734.

Gardner, John. "Legal Positivism: 51/2 Myths." The American Journal of Jurisprudence 46, no. 1 (June 2001): 199-227.

Gaus, Gerald, The Order of Public Reason: A Theory of Freedom and Morality in a Diverse and Bounded World. Cambridge: Cambridge University Press, 2011.

Gluck, Abbe R. and Lisa Schultz Bressman. "Statutory Interpretation from the Inside - An Empirical Study of Congressional Drafting, Delegation, and the Canons: Part I." Stanford Law Review 65, no. 5 (May 2013): 901-1025.

Hadfield, Gillian K. and Barry R. Weingast. "What is Law? A Coordination Model of the Characteristics of Legal Order." Journal of Legal Analysis 4, no. 1 (2012): 1-44.

Hardin, Russell. Trust. Cambridge: Polity Press, 2006. 
Hart, Henry M. and Albert M. Sacks. The Legal Process: Basic Problems in the Making and Application of Law. Edited by William N. Eskridge and Philip P. Frickey. Westbury, NY: Foundation Press, 1994.

Hume, David. A Treatise of Human Nature. Edited by L. A. Selby-Bigge. Oxford: Clarendon Press, 1886.

Jones, Karen. "Trust as an Affective Attitude.” Ethics 107, no. 1 (October 1996): 4-25.

Katzmann, Robert A. Judging Statutes. New York: Oxford University Press, 2014.

Kavanaugh, Brett M. "Review of Judging Statutes by Robert A. Katzmann." Harvard Law Review 129, no. 8 (June 2016): 2118-2163.

Kolber, Adam. "Supreme Judicial Bullshit." Arizona State Law Journal 50, no. 1 (Spring 2018): 141-178.

Lenard, Patti Tamara. "The Political Philosophy of Trust and Distrust in Democracies and Beyond.” The Monist 98, no. 4 (October 2015): 353-359.

Light, Matthew. "Police reforms in the Republic of Georgia: the convergence of domestic and foreign policy in an anti-corruption drive." Policing and Society 24, no. 3 (2014): 318345.

Liptak, Adam. "An Exit Interview with Richard Posner, Judicial Provocateur." N.Y. Times (New York, NY) Sept. 11, 2017, https://www.nytimes.com/2017/09/11/us/politics/judgerichard-posnerretirement.html.

Llewellyn, Karl N. "Remarks on the Theory of Appellate Decision and the Rules or Canons of About How Statutes are to be Construed." Vanderbilt Law Review 3, no. 3 (1950): 395-405.

Manning, John. "Textualism as a Nondelagation Doctrine." Columbia Law Review 97, no. 3 (April 1997): 673-737.

Manning, John F. "What Divides Textualists from Purposivists?” Columbia Law Review 106, no. 1 (January 2006): 70-111.

Nelson, Caleb. “What is Textualism?” Virginia Law Review 91, no. 2 (April 2005): 347-418.

Nickel, Philip J. “Trust, Staking, and Expectations.” Journal for the Theory of Social Behaviour 39, no. 3 (August 2009): 345-362.

Nourse, Victoria F. \& Anita S. Krishnakumar. "Canon Wars.” Texas Law Review 97, no. 1 (November 2018): 163-191.

Rousseau, Jean-Jacques. Discourse on Inequality (1754) reprinted in Rousseau: The Discourses and Other Early Political Writing. Edited and translated by Victor Gourevitch. New York: Cambridge University Press, 1997. 
Scalia, Antonin. "The Rule of Law as a Law of Rules." University of Chicago Law Review 56, no. 4 (Autumn 1989): 1175-1188.

Scalia, Antonin and Bryan A. Garner. Reading Law: The Interpretation of Legal Texts. St. Paul, MN: West Publishing Company, 2012.

Schauer, Frederick. "Formalism.” Yale Law Journal 97, no. 4 (March 1988): 509-548.

Schauer, Frederick. "Statutory Construction and the Coordinating Function of Plain Meaning." Supreme Court Review 7 (1990): 231-256.

Schauer, Frederick. "The Practice and Problems of Plain Meaning: A Response to Aleinikoff and Shaw." Vanderbilt Law Review 45, no. 3 (April 1992): 715-41.

Shapiro, Scott. Legality. Cambridge: Harvard University Press, 2011.

Skyrms, Brian. The Stag Hunt and the Evolution of Social Structure. New York: Cambridge University Press, 2012.

Smolchenko, Anna. "Medvedev Address Hints at Change." Moscow Times (Moscow, Russia), January 23, 2008.

Sztompka, Piotr. Trust: A Sociological Theory. Cambridge: Cambridge University Press, 2000.

Turchin, Peter and Sergey A. Nefedov. Secular Cycles. Princeton: Princeton University Press, 2009.

Tyler, Tom R. Why People Obey the Law. New Haven: Yale University Press, 1990.

Vermeule, Adrian. "Legislative History and the Limits of Judicial Competence: The Untold Story of Holy Trinity Church." Stanford Law Review 50, no. 6 (July 1998): 1833-1896.

Waldron, Jeremy. Law and Disagreement. New York: Oxford University Press, 1999. 